\title{
Enhancement of User-Centered Design Method for Improving Usability of E-Learning Website Design
}

\author{
Atqia Aulia ${ }^{1}$, Gede Putra Kusuma ${ }^{2}$ \\ ${ }^{1}$ Computer Science Department, BINUS Graduate Program - Master of Computer Science, \\ Bina Nusantara University, Jakarta, Indonesia, 11480, atqia.aulia@ binus.ac.id \\ ${ }^{2}$ Computer Science Department, BINUS Graduate Program - Master of Computer Science, \\ Bina Nusantara University, Jakarta, Indonesia, 11480, inegara@binus.edu
}

\begin{abstract}
User-Centered Design method is one of the methods used to design a good interactive website with a high usability value. At each stage of the process, this method centers around user to improve usability of a website and User Interface of an application. However, there are a few disadvantages of this method as mentioned in this research [1]. For that reason, we have made some improvements to the User-Centered Design method and perform a test on an e-learning website. These tests conclude that the proposed User-Centered Design method is better than the previous User-Centered Design method, with the result of SUS calculation showing grade 65.08 for the previous User-Centered Design method and grade 75.54 for the proposed User-Centered Design method. The t-Test results also indicate that there is a significant effect on the use of the proposed User-Centered Design method compared to the previous User-Centered Design method.
\end{abstract}

Key words: E-learning, system usability scale, user-centered design, user experience, website design.

\section{INTRODUCTION}

User-Centered Design (UCD) is a multidisciplinary design approach based on the active involvement of users to improve the understanding of user and task requirements, and the iteration of design and evaluation [2]. This method centers around user and its main concern is the usability of website's and application's User Interface [3]. Usability is an assessment of an extent to which a product can be used by user to achieve effective and efficient system goals so that user would be satisfied [4].

But in its development, the User-Centered Design method has some disadvantages. As explained by [1] that the User-Centered Design method is not able to analyze user's needs and product functions simultaneously because the User-Centered Design method only focuses on the needs of users, thus aside the function of the product itself. As also mention in study [5], the considered of software systems and met user expectations and business performance goals are not an easy job. The User-Centered Design also requires a special design team to translate the user desires well so that it could be applied to the product. The deficiencies mentioned in this journal are supported by the document [6] which is the ISO standard for the User-Centered Design method itself.

Based on its disadvantages of UCD method, we propose a User-Centered Design method and test it on the Moodle-based e-learning website. Modification of the User-Centered Design method is adopting the process of the Requirement Engineering method, which is Requirement Elicitation and Requirement Specification.

\section{RELATED WORKS}

Research conducted by [7] discusses the process of combining several software development methods, such as User-Centered Design and Agile Software Development to produce a newly proposed method, which is User-Centered Agile Software Development (UCASD). This method can be applied as a system development method that is easy to use. The results showed that the combination of the UCD and Agile methods had five main principles, which are separating product discovery and product creation, iterative design and system development, interrelated stages, being continuous and involving stakeholders, and artifact-mediated communication.

Research conducted by [8] aims to design e-learning websites using a User-Centered Design approach. The issue in this journal is translating the pedagogy problem into a software tool that can support an effective learning system. The focus of designing this e-learning website is interesting content, based on user needs, and appearance containing pedagogy or school educational background. Website evaluation involves three users who are administration, teachers, and students.

Research [9] presents website remodeling using User-Centered Design methods and usability testing. This study mentioned that usability testing is one way to test User-Centered Design methods. Testing using usability testing is conducted by inviting several respondents to use the 
website. Then respondents will be given time to answer some questions that have been prepared previously regarding the experience of using the website. The results show that testing during the design process is an effective way to build a website. In addition to reflecting user needs and preferences, the system would be also easily changed according to existing test results.

The research [10] aims to eliminate the gap between system development and Human Computer Interaction (HCI) by proposing to create a new method, which combines the usability engineering method with interaction design to produce the User-Centered Systems Design method (UCSD). The results showed that the UCSD method was successfully applied in building a system in which the system had focused on user throughout the implementation phase.

The research [1] aims to redesign the appearance of the DAISY interface, a reading aid system, by enhancing the interface features using the User-Centered Design process. Not only uses the use of User-Centered Design methods in developing systems, but this research also combines other systems development methods, such as Goal, Operation, Method and Selection (GOMS) as well as the Usability Testing method for its evaluation method. In this journal, it is mentioned several advantages and disadvantages of each method used, including the User-Centered Design method.

\section{RESEARCH METHODOLOGY}

The general step of User-Centered Design-based methods [6] can be seen in Figure 1.

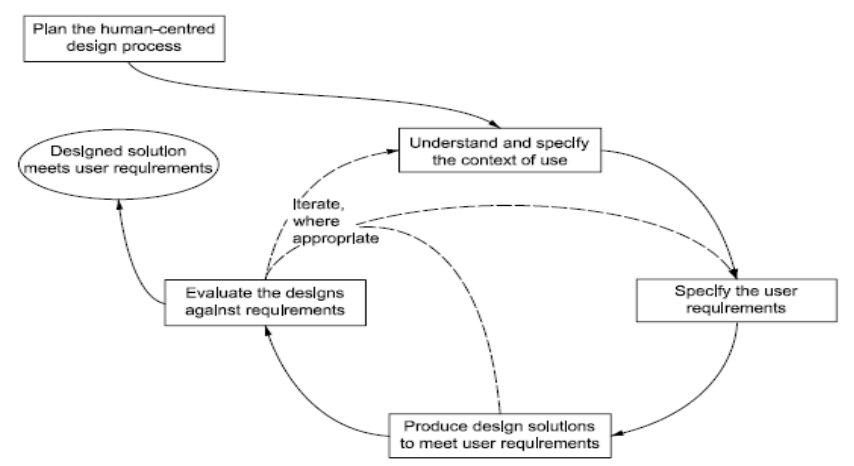

Figure 1: General Step of the User-Centered Design Method

The proposed method of User-Centered Design is adopted based on the Requirements Engineering method, which are the Elicitation and Specification stage. Requirement Engineering is the process of gathering the requirements and needs of stakeholders and developing them into detailed and agreed requirements, documented and determined [11].

An illustration of the proposed User-Centered Design method with the addition of the Elicitation and Specification process can be seen in Figure 2. Details of each stage can be seen in the next point.

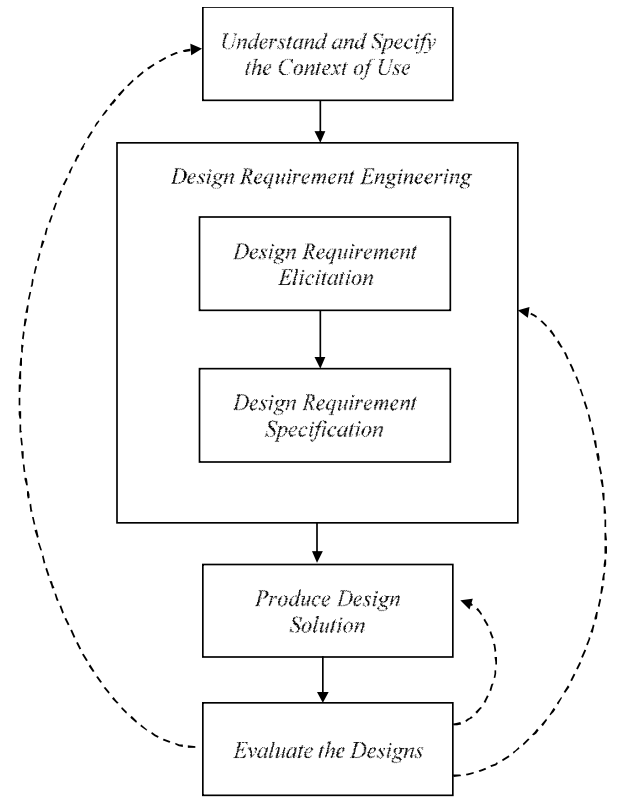

Figure 2: Proposed User-Centered Design Method

\subsection{Understand and Specify the Context of Use}

The first stage of the proposed method of User-Centered Design is to understand and specify the context of use. This stage aims to identify users who will be e-learning website users. This research was conducted at Cinta Kasih Tzu Chi High School, South Jakarta.

In selecting the target user or sample of respondents, we used a non-probability sampling technique with the sample technique used is purposive sampling. We determine the target users of e-learning websites are high school students of Cinta Kasih Tzu Chi majoring in science with the age range of 15-18 years, as many as 90 students as research populations and teachers of Cinta Kasih Tzu Chi high school aged 25-45 in the year of 50 teachers as the study population, so the total research population was 140 respondents. Sampling in this study uses the Taro Yamane formula [12] with a precision of $10 \%$ with a confidence level of $90 \%$, which is as follows.

$n=\frac{N}{N d^{2}+1}=\frac{140}{140(01)^{2}+1}=58,33=59$

From the above calculation, the minimum sample that will be used in this study is 59 respondents. However, we fulfilled respondents to 60 respondents, in case some sample were invalid/biased, and were supported by the theory of sampling according to [13] that the more samples are taken, the less likely the research error.

Out of the 60 respondents, we describe and classify the users into User Persona. User Persona will assist us in analyzing the type of user and recognizes that each user has different needs and expectations in using an application [14]. Figure 3 shows one of the User Persona that used in this research. 


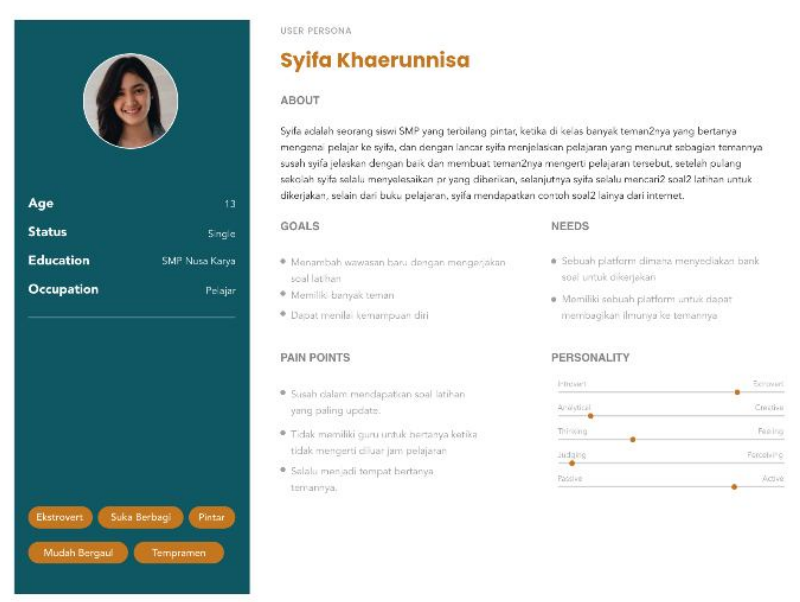

Figure 3: User Persona

\subsection{Design Requirement Engineering}

The next stage of the research is the adoption of the Requirement Engineering phase, which are the Requirement Elicitation and Requirement Specification stages. Changing the name of the stages is adjusted to the research needs, which is to become the Design Requirement Elicitation and Design Requirement Specification. The details of the actors from each stage of the Design Requirement Engineering can be seen in Figure 4.

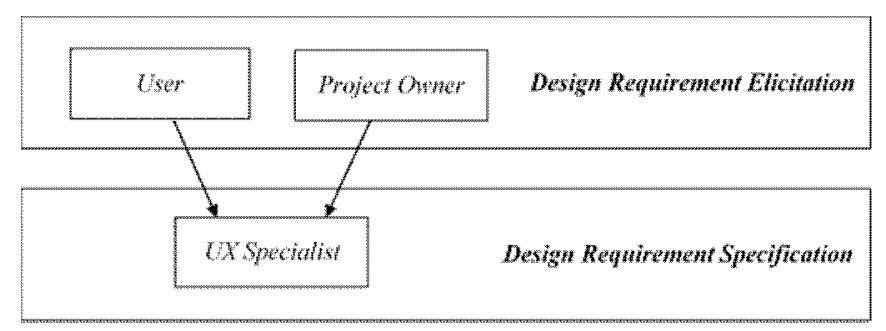

Figure 4: Actor of the Design Requirement Engineering

\section{A. Design Requirement Elicitation}

At this stage, we collected data on system requirements by distributing questionnaires as the medium for research data collection. The questionnaire's questions were taken from several research journals and followed the System Usability Scale questionnaire. System Usability Scale (SUS) is one of the user test methods that provide reliable "quick and dirty" measuring devices. This user test method was introduced by John Brooke [15] which can be used to evaluate various types of products or services, including software, mobile devices, websites, and applications [16].

There is a total of 19 questions consisting of 9 questions relating to feedback and user needs for e-learning websites and 10 questions using the SUS standard questionnaire. The results of the initial questionnaire data collection can be seen in Table 1.
Table 1: Result of Initial Questionnaire

\begin{tabular}{|c|c|}
\hline Question & Results \\
\hline $\begin{array}{l}\text { Do you } \\
\text { understand the } \\
\text { display language } \\
\text { in Indonesian or in } \\
\text { English? }\end{array}$ & $\begin{array}{l}59 \% \text { choose Indonesian, } 33 \% \text { choose } \\
\text { both, and } 8 \% \text { choose English }\end{array}$ \\
\hline $\begin{array}{l}\text { What about the } \\
\text { display color on } \\
\text { the website? }\end{array}$ & $\begin{array}{l}46 \% \text { answered Average, } 43 \% \\
\text { answered Interesting, } 7 \% \text { answered } \\
\text { Less Interesting, and } 5 \% \text { answered } \\
\text { Very Attractive }\end{array}$ \\
\hline $\begin{array}{l}\text { What color is best } \\
\text { applied to the } \\
\text { website? }\end{array}$ & $\begin{array}{l}34 \% \text { dominant choose Blue or bright } \\
\text { color }\end{array}$ \\
\hline $\begin{array}{l}\text { Can you easily } \\
\text { read the text on } \\
\text { the website? }\end{array}$ & $\begin{array}{l}93 \% \text { of users can easily read the posts } \\
\text { on the website }\end{array}$ \\
\hline $\begin{array}{l}\text { What do you think } \\
\text { about the layout of } \\
\text { menu and feature? }\end{array}$ & $\begin{array}{l}52 \% \text { of users answered Confusing } \\
\text { and } 48 \% \text { answered Not Confusing }\end{array}$ \\
\hline $\begin{array}{l}\text { Of the features } \\
\text { available, what } \\
\text { features do you } \\
\text { need the most? }\end{array}$ & $\begin{array}{l}\text { Teacher answers Create Questions, } \\
\text { Assignments and Quizzes. Student } \\
\text { answers Learning Materials, Exercise } \\
\text { Questions, and Explains the Answers }\end{array}$ \\
\hline $\begin{array}{l}\text { Of the feature } \\
\text { available, what } \\
\text { features that's not } \\
\text { needed? }\end{array}$ & $\begin{array}{l}36 \% \text { of users answered nothing, } 16 \% \\
\text { answered Summary, and the } \\
\text { remaining } 48 \% \text { of users answered } \\
\text { calendar, studied videos and } \\
\text { calculators }\end{array}$ \\
\hline $\begin{array}{l}\text { Are there } \\
\text { additional features } \\
\text { you need, which } \\
\text { aren't on the } \\
\text { website yet? }\end{array}$ & $\begin{array}{l}54 \% \text { of users answered several } \\
\text { additional features such as chatting, } \\
\text { analysis of learning, webcam, and } \\
\text { mini quizzes. }\end{array}$ \\
\hline $\begin{array}{l}\text { I think that I } \\
\text { would like to use } \\
\text { this system. }\end{array}$ & $\begin{array}{l}52 \% \text { answered Undecided (3) } \\
30 \% \text { answered Agree (4) } \\
10 \% \text { answered Strongly Agree (5) } \\
5 \% \text { answered Disagree (2) } \\
3 \% \text { answered Strongly Disagree (1) }\end{array}$ \\
\hline $\begin{array}{l}\text { I found the system } \\
\text { unnecessarily } \\
\text { complex }\end{array}$ & $\begin{array}{l}41 \% \text { answered Undecided (3) } \\
31 \% \text { answered Disagree (2) } \\
20 \% \text { answered Agree (4) } \\
1 \% \text { answered Strongly Disagree (1) } \\
3 \% \text { answered Strongly Agree (5) }\end{array}$ \\
\hline $\begin{array}{l}\text { I thought the } \\
\text { system was easy } \\
\text { to use. }\end{array}$ & $\begin{array}{l}41 \% \text { answered Undecided (3) } \\
39 \% \text { answered Agree (4) } \\
13 \% \text { answered Strongly Agree (5) } \\
7 \% \text { answered Disagree (2) } \\
0 \% \text { answered Strongly Disagree (1) }\end{array}$ \\
\hline $\begin{array}{l}\text { I think that I } \\
\text { would need the } \\
\text { support of a } \\
\text { technical person } \\
\text { to be able } \\
\text { to use this system. }\end{array}$ & $\begin{array}{l}43 \% \text { answered Undecided (3) } \\
21 \% \text { answered Agree (4) } \\
15 \% \text { answered Disagree (2) } \\
13 \% \text { answered Strongly Agree (5) } \\
8 \% \text { answered Strongly Disagree (1) }\end{array}$ \\
\hline $\begin{array}{l}\text { I found the } \\
\text { various functions } \\
\text { in the system were } \\
\text { well integrated. }\end{array}$ & $\begin{array}{l}38 \% \text { answered Undecided (3) } \\
33 \% \text { answered Agree (4) } \\
25 \% \text { answered Strongly Agree (5) } \\
5 \% \text { answered Disagree (2) }\end{array}$ \\
\hline
\end{tabular}




\begin{tabular}{|c|c|}
\hline & $0 \%$ answered Strongly Disagree (1) \\
\hline $\begin{array}{l}\text { I thought there } \\
\text { was too much } \\
\text { inconsistency in } \\
\text { this system. }\end{array}$ & $\begin{array}{l}34 \% \text { answered Disagree (2) } \\
31 \% \text { answered Undecided (3) } \\
20 \% \text { answered Strongly Disagree (1) } \\
13 \% \text { answered Agree (4) } \\
2 \% \text { answered Strongly Agree (5) }\end{array}$ \\
\hline $\begin{array}{l}\text { I would imagine } \\
\text { that most people } \\
\text { would learn to use } \\
\text { this system } \\
\text { very quickly. }\end{array}$ & $\begin{array}{l}41 \% \text { answered Undecided (3) } \\
31 \% \text { answered Agree (4) } \\
16 \% \text { answered Strongly Agree (5) } \\
11 \% \text { answered Disagree (2) } \\
0 \% \text { answered Strongly Disagree (1) }\end{array}$ \\
\hline $\begin{array}{l}\text { I found the system } \\
\text { very cumbersome } \\
\text { to use. }\end{array}$ & $\begin{array}{l}46 \% \text { answered Undecided (3) } \\
23 \% \text { answered Disagree (2) } \\
21 \% \text { answered Strongly Disagree (1) } \\
10 \% \text { answered Agree (4) } \\
0 \% \text { answered Strongly Agree (5) }\end{array}$ \\
\hline $\begin{array}{lr}\text { I felt } & \text { very } \\
\text { confident } & \text { using } \\
\text { the system. } & \end{array}$ & $\begin{array}{l}39 \% \text { answered Undecided (3) } \\
31 \% \text { answered Agree (4) } \\
21 \% \text { answered Strongly Agree (5) } \\
8 \% \text { answered Disagree (2) } \\
0 \% \text { answered Strongly Disagree (1) }\end{array}$ \\
\hline $\begin{array}{l}\text { I needed to learn a } \\
\text { lot of things } \\
\text { before I could get } \\
\text { going with this } \\
\text { system. }\end{array}$ & $\begin{array}{l}30 \% \text { answered Strongly Agree (5) } \\
28 \% \text { answered Undecided (3) } \\
25 \% \text { answered Agree (4) } \\
10 \% \text { answered Disagree (2) } \\
8 \% \text { answered Strongly Disagree (1) }\end{array}$ \\
\hline $\begin{array}{l}\text { Overall, what do } \\
\text { you think of this } \\
\text { website? Please } \\
\text { provide your input } \\
\text { regarding the } \\
\text { website. }\end{array}$ & $\begin{array}{l}30 \% \text { of users expect an improvement } \\
\text { in appearance by adding animation } \\
\text { and simplifying the operation } \\
\text { process. }\end{array}$ \\
\hline
\end{tabular}

In parallel, we also conduct system requirements interviews with the project owner of the e-learning website. There are 20 questions asked to the project owner. The results of interviews can be seen in Table 2.

Table 2: Result of Project Owner Interview

\begin{tabular}{|c|c|}
\hline Question & Results \\
\hline $\begin{array}{l}\text { What was the } \\
\text { initial idea of } \\
\text { making } \\
\text { e-learning? }\end{array}$ & $\begin{array}{l}\text { Making lessons can be more effective } \\
\text { in achieving lesson objectives. }\end{array}$ \\
\hline $\begin{array}{l}\text { Who are the } \\
\text { stakeholders in } \\
\text { this e-learning? }\end{array}$ & $\begin{array}{l}\text { The schools, school administration } \\
\text { staff, teachers, students, and parents } \\
\text { of the students. }\end{array}$ \\
\hline $\begin{array}{l}\text { Who is your target } \\
\text { market? }\end{array}$ & $\begin{array}{l}\text { The target users are users who are } \\
\text { accustomed to operating computers } \\
\text { or already have basic skills using a } \\
\text { computer, even though they have } \\
\text { never used e-learning before. }\end{array}$ \\
\hline $\begin{array}{l}\text { What are the main } \\
\text { features or core of } \\
\text { this e-learning? }\end{array}$ & $\begin{array}{l}\text { Additional features such as } \\
\text { gamification and interactivity } \\
\text { improvement for student, as in } \\
\text { location-based learning, and } \\
\text { ability-based learning. }\end{array}$ \\
\hline $\begin{array}{l}\text { What problem do } \\
\text { you want to solve } \\
\text { through this }\end{array}$ & $\begin{array}{l}\text { Making lessons can be more } \\
\text { effective. I see that technology can } \\
\text { help effectiveness in learning, not to }\end{array}$ \\
\hline
\end{tabular}

\begin{tabular}{|c|c|}
\hline e-learning? & $\begin{array}{l}\text { eliminate the teacher's function, but } \\
\text { as a tool to help to learn. }\end{array}$ \\
\hline $\begin{array}{l}\text { When is the } \\
\text { launch target? }\end{array}$ & $\begin{array}{l}\text { In terms of research, there are } \\
\text { improvements from the previous } \\
\text { website. But from a commercial } \\
\text { perspective, as long as it meets the } \\
\text { needs of the user can already publish. }\end{array}$ \\
\hline $\begin{array}{l}\text { What do you } \\
\text { expect when users } \\
\text { use } \\
\text { e-learning? }\end{array}$ & $\begin{array}{l}\text { I hope all users can be independent, } \\
\text { intuitive, even though there are } \\
\text { difficulties on the website, there is } \\
\text { good and informative documentation } \\
\text { for them to follow. }\end{array}$ \\
\hline $\begin{array}{l}\text { What are your } \\
\text { reasons do you } \\
\text { use Moodle? }\end{array}$ & $\begin{array}{l}\text { Because it is open source and can be } \\
\text { customized. }\end{array}$ \\
\hline $\begin{array}{l}\text { What are your } \\
\text { challenges in this } \\
\text { project? }\end{array}$ & $\begin{array}{l}\text { Educating clients, schools, } \\
\text { introducing new technologies that } \\
\text { they have never used, how to create } \\
\text { user guide documents that are easy } \\
\text { for users to follow ultimately make } \\
\text { them able and willing to explore } \\
\text { further. }\end{array}$ \\
\hline $\begin{array}{lcr}\text { What } & \text { kind } & \text { of } \\
\text { design } & \text { do } & \text { you } \\
\text { want? } & & \end{array}$ & $\begin{array}{l}\text { Interesting and following current } \\
\text { developments. }\end{array}$ \\
\hline $\begin{array}{l}\text { What color do you } \\
\text { want in } \\
\text { e-learning? }\end{array}$ & $\begin{array}{l}\text { Pastel colors, light blue, and many } \\
\text { animations or images. }\end{array}$ \\
\hline $\begin{array}{l}\text { What language do } \\
\text { you want to use? }\end{array}$ & $\begin{array}{l}\text { Indonesian is the default, but there are } \\
\text { also bilingual features, which must } \\
\text { use communicative language. }\end{array}$ \\
\hline $\begin{array}{l}\text { From the existing } \\
\text { e-learning, is there } \\
\text { any confusing } \\
\text { part? }\end{array}$ & $\begin{array}{l}\text { Some setting features in Admin and } \\
\text { some forms that are less necessary to } \\
\text { be displayed and filled out by } \\
\text { Teacher and Admin }\end{array}$ \\
\hline $\begin{array}{l}\text { What are the parts } \\
\text { that you want to } \\
\text { keep from } \\
\text { e-learning? }\end{array}$ & $\begin{array}{l}\text { Maintain the functions of each user, } \\
\text { Admin, Teacher, and Student }\end{array}$ \\
\hline $\begin{array}{l}\text { What features and } \\
\text { menus do you } \\
\text { want to display on } \\
\text { the dashboard? }\end{array}$ & $\begin{array}{l}\text { The dashboard in general is a big } \\
\text { picture of the functions of each role } \\
\text { user. }\end{array}$ \\
\hline $\begin{array}{l}\text { How many roles } \\
\text { are there in } \\
\text { e-learning? }\end{array}$ & $\begin{array}{l}\text { There are three role users, which are } \\
\text { Admin, Teacher, and Student. }\end{array}$ \\
\hline $\begin{array}{l}\text { What features do } \\
\text { you want to get rid } \\
\text { of from existing } \\
\text { e-learning? }\end{array}$ & $\begin{array}{l}\text { Admin setting features and some } \\
\text { forms that are not necessary when } \\
\text { inputting classes and subjects. }\end{array}$ \\
\hline $\begin{array}{l}\text { Are there } \\
\text { additional features } \\
\text { that you want to } \\
\text { include in this } \\
\text { e-learning? }\end{array}$ & $\begin{array}{l}\text { In the discussion section, it is not only } \\
\text { the teacher who can add discussion } \\
\text { topics but in terms of students also } \\
\text { can add discussion topics themselves. } \\
\text { Because it is feared the teacher did } \\
\text { not post maple discussions. }\end{array}$ \\
\hline $\begin{array}{l}\text { Which part or } \\
\text { feature is not what } \\
\text { you want yet? }\end{array}$ & $\begin{array}{l}\text { Website coloring, flow, and } \\
\text { appearance that are less attractive and } \\
\text { too many steps to achieve a task. }\end{array}$ \\
\hline
\end{tabular}




\section{B. Design Requirement Specification}

From the results of the initial stage questionnaire and the project owner interview, the next stage of the research is to analyze the improvement for the e-learning website with UX Specialists. The UX Specialist in this study is Dadhi Quardanu, who is a Head of UX in GOJEK company.

Analysis and discussion of the results with UX Specialist serve as a middle ground to avoid gaps or balance between user needs, product functions, and system requirements in terms of business. UX Specialist also functions as a guide or director related to the design and appearance of e-learning websites. The implementation of the list gap design that we discussed with UX Specialist can be seen in the next stage, which is Produce Design Solution.

\subsection{Product Design Solution}

After getting the system requirements, the next step is to pour it into a design solution. There are two website design models that we built, which is website design using the User-Centered Design method and website design using the proposed User-Centered Design method. In building the two design models, we use the Sketch application version 10.13.4.

The results of the solutions that have been made by UX Specialists are implemented into real design solutions. A detailed explanation of each component in that solution can be seen in the Figures 5 until 14.

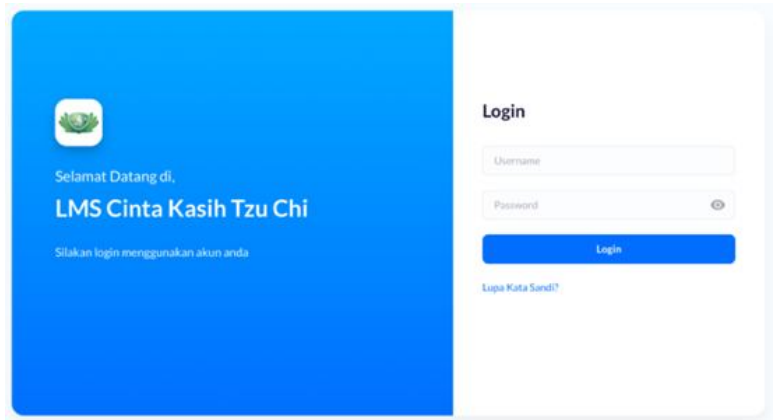

Figure 5: Changes the website theme to bright blue colors and additional animation

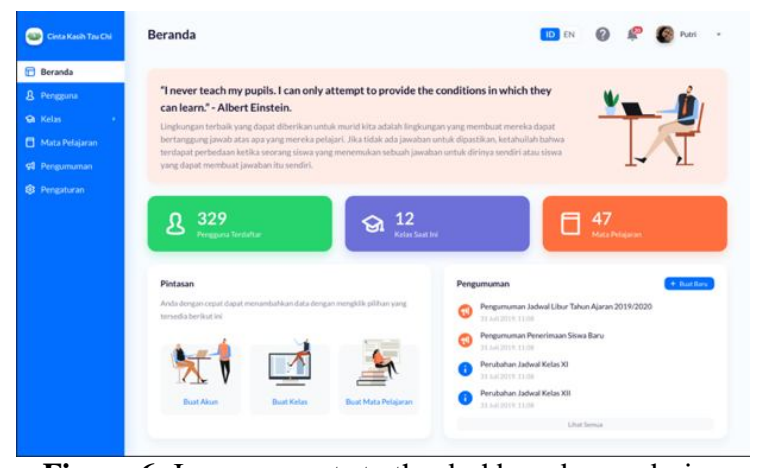

Figure 6: Improvements to the dashboard page design

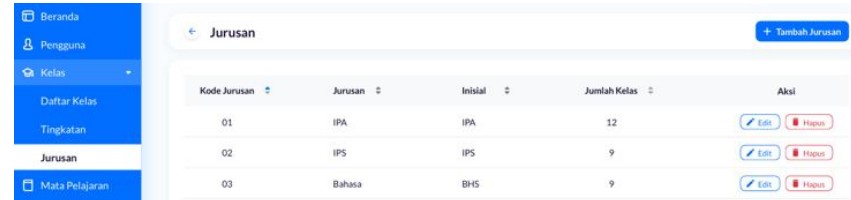

Figure 7: In making classes there are additional arrangements for class levels and class majors

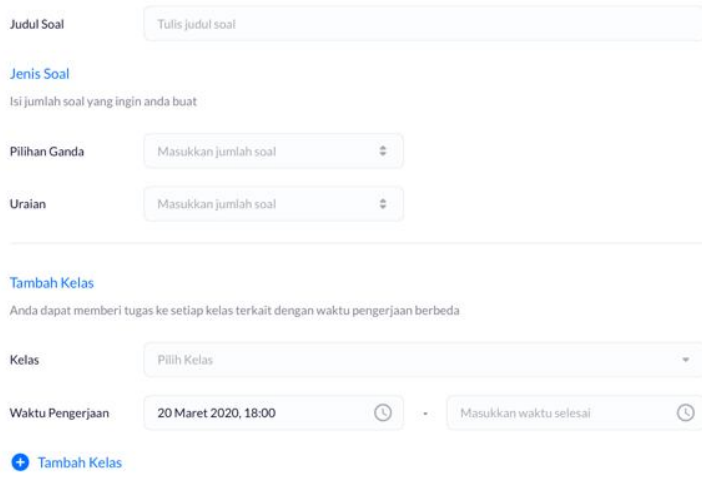

Figure 8: The assignment settings can be set to specific classes or all classes

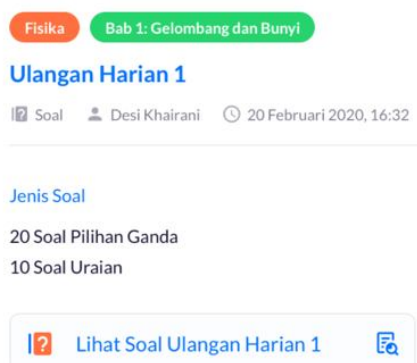

Figure 9: Added quick view to see the problem in the task list

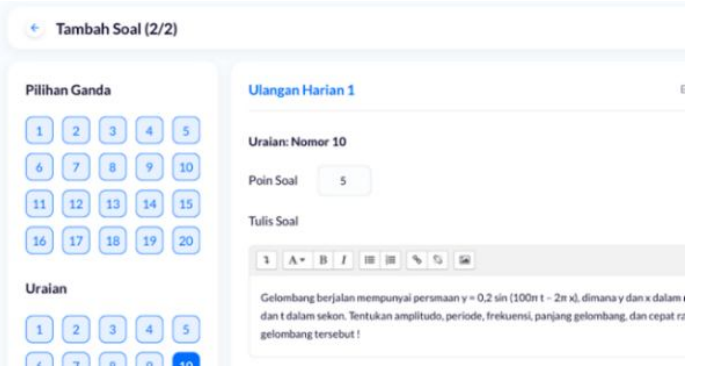

Figure 10: In making questions there are weight point for questions that can be changed according to the needs of the teacher

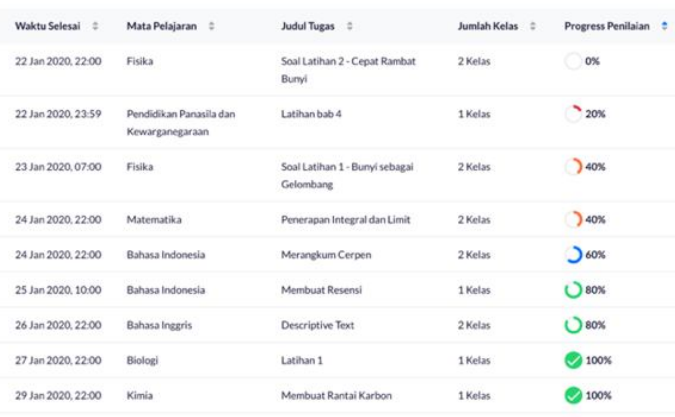

Figure 11: The progress assessment uses the radial progress bar and changes colors according to the progress value 


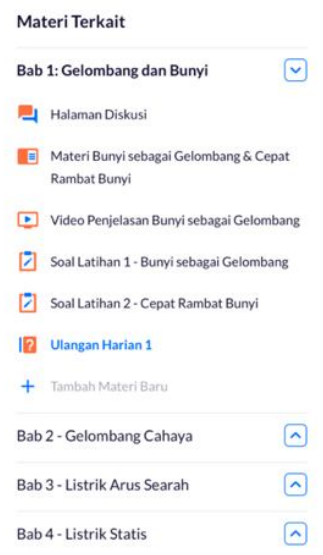

Figure 12: Add related material section in material details for material navigation

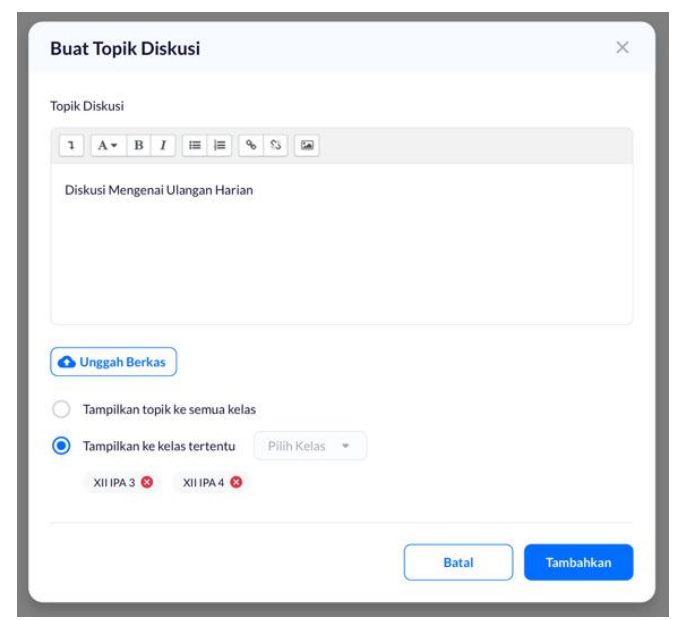

Figure 13: Discussion topics can be arranged based on specific classes or all classes and students can create their discussion topics

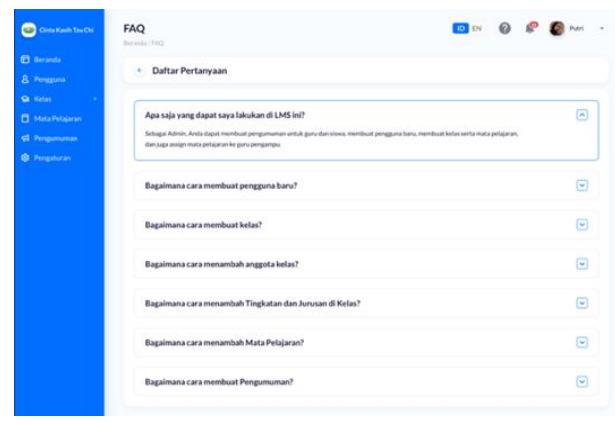

Figure 14: Added FAQ feature for all role users

After designing the website's appearance, the next step is to build a high-fidelity website prototype. With this prototype, users can interact directly with the design model, so that the feedback obtained will be more in line with what is expected. In building prototypes, we use the InVision App tools as shown in Figure 15.
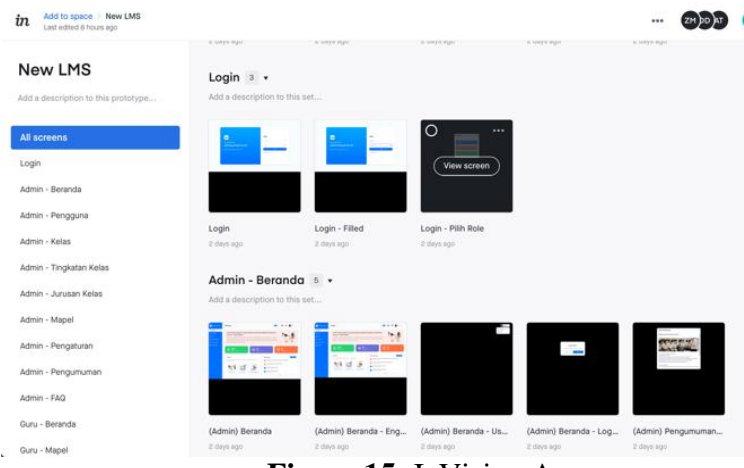

Figure 15: InVision App

\subsection{Evaluate the Designs}

The last stage of the proposed method is the Evaluate the Designs stage. At this stage, we test the design that has been implemented into a prototype e-learning website. Evaluation is aims to validate whether the prototype is following system requirements or not.

\section{A. Test Validity and Reliability of Research Instruments}

Based on [17], validity is a measure that shows the level of validity of an instrument. In the validity test, the test criteria by comparing the $r$ count with $r$ table, if $r$ count $>r$ table, then the instrument is considered valid, conversely if $r$ count $<r$ table is considered invalid (drop), so the instrument cannot be used in research. The items on the evaluation questionnaire are 18 items, through statistical calculations, there are 12 valid items and 6 invalid items (drop). The magnitude of $r$ count ranges from 0,044 to 0,559 , while the magnitude of $r$ count with $\mathrm{n}=40$ and the significance level of $5 \%$ is 0,312 .

For reliability testing, questionnaire testing is performed on valid items. The reliability test results for the questionnaire were 0,869 . Because $r$ count $>r$ table $(0,869>0,312)$, the questionnaire is reliable or reliable. The results can be seen in the Table 3 .

Table 3: Reliability Statistics

\begin{tabular}{|lll|r|}
\hline Cronbach's Alpha & Part 1 & Value & .595 \\
& & N of Items & $6^{\mathrm{a}}$ \\
& Part 2 & Value & .592 \\
& & N of Items & $6^{\mathrm{b}}$ \\
& Total N of Items & 12 \\
Correlation Between Forms & & .770 \\
Spearman-Brown Coefficient & Equal Length & .870 \\
& Unequal Length & .870 \\
Guttman Split-Half Coefficient & & .869 \\
\hline
\end{tabular}

a. The items are: No.1, No.2, No.3, No.6, No.7, No.9.

b. The items are: No.10, No.12, No.14, No.16, No.17, No.18. 


\section{B. Evaluation Scenarios}

Before conducting the test, we first make a test plan in the form of a scenario. This testing scenario will be the basic of testing that we will do. Test scenarios as follows:

"You are a student/teacher who is conducting teaching and learning activities in school. Please use the prototype e-learning website to create classes, make subjects, make materials, and assess questions that have been made."

\section{Data Collection Evaluation}

In the design evaluation stage, respondents will assess two different prototypes according to the test scenario described in the previous point.

After testing, we provide a questionnaire as an evaluation material for each prototype. The evaluation questionnaire that had been validated in the previous stage consisted of 22 questions, of which 12 questions were questions the needs of users of the e-learning website and 10 questions were standard SUS questionnaires.

\section{SUS Calculation}

After collecting data, we analyzed the usability value on the evaluation questionnaire. Usability studies are very important to ensure users feel comfortable with the application and meet their respective expectations when using the application [18]. There are two evaluation questionnaire results: Website 1 evaluation questionnaire, which is a website that was built using the User-Centered Design method and Website 2 evaluation questionnaire, which is a website that was built using the proposed User-Centered Design method.

There are 10 questions of SUS with an answer scale of 1 to 5 . For the calculation of the SUS results, each question is odd numbered, the value is reduced by $1(\mathrm{X}-1)$ and for each question even numbered, reduce the value by $5(5-X)$. Then add up the values of the even numbered and odd numbered statements to get the total SUS value on the Website 1 evaluation questionnaire. Then the total SUS value is averaged and multiplied by the value 2.5. The SUS calculation value can be interpreted as shown in Table 4 .

Table 4: Interpretation of SUS Score

\begin{tabular}{|c|c|c|}
\hline SUS Score & Grade & Rating \\
\hline$>80.3$ & A & Extraordinary \\
\hline $68-80.3$ & B & Good \\
\hline 68 & C & Okay \\
\hline $51-68$ & D & Poor \\
\hline$<51$ & E & Awful \\
\hline
\end{tabular}

\section{SUS Calculation for User-Centered Design Method}

We calculate the average value of the questionnaire based on the formula:

$$
\bar{x}=\frac{\sum x}{n}=\frac{1562}{60}=26.03
$$

The average questionnaire score is 26.03. Next look at the SUS value for the entire questionnaire.

$$
\text { SUS }=\bar{x} * 2.5=26.03 * 2.5=65.08
$$

From the calculation formula, the total SUS calculation result for the User-Centered Design website gets a value of 65.08 with grade D or rated "Poor".

SUS Calculation Proposed User-Centered Design Method We calculate the average value of the questionnaire based on the formula:

$\bar{x}=\frac{\sum x}{n}=\frac{1813}{60}=30.22$

The average questionnaire score is 30.22 . Next look at the SUS value for the entire questionnaire.

$305=\bar{x} \approx 2.5=30.22 \times 2.5=75.54$

From the calculation formula, the total SUS calculation result for the proposed User-Centered Design gets a value of 75.54 with grade B or rated "Good".

\section{RESULTS AND DISCUSSION}

The evaluation of this research conducted using t-Test. If the results of the t-Test show a difference between the prototype that was built with the User-Centered Design method and the prototype that was built using the proposed User-Centered Design method, then the design uses the proposed method better than the previous method and this research is considered successful.

\subsection{Hypothesis Formula}

The research hypothesis can be arranged as follows. $\mathrm{HO}=$ There is no significant difference in the usability of the two websites

$\mathrm{H} 1=$ There is a significant difference in the usability of the two websites

\subsection{Normality Test}

Normality test is calculation using the SPSS program. The normality test criteria if the Sig. $>0.05$, it can be concluded that the data come from normally distributed samples. The results can be seen in the Table 5 .

Table 5: Tests of Normality

\begin{tabular}{|l|r|r|r|r|r|r|}
\hline \multirow{2}{*}{} & \multicolumn{3}{|c|}{ Kolmogorov-Smirnov ${ }^{\mathrm{a}}$} & \multicolumn{3}{|c|}{ Shapiro-Wilk } \\
\cline { 2 - 7 } & \multicolumn{1}{|c|}{ Statistic } & \multicolumn{1}{c|}{$\mathrm{df}$} & \multicolumn{1}{c|}{ Sig. } & Statistic & \multicolumn{1}{c|}{$\mathrm{df}$} & \multicolumn{1}{c|}{ Sig. } \\
\hline Website1 & .100 & 60 & $.200^{*}$ & .985 & 60 & .644 \\
Website2 & .109 & 60 & .071 & .912 & 60 & .000 \\
\hline
\end{tabular}

From the above results, we see in the Kolmogorov-Smirnov column and can be seen that the significance value for 
Atqia Aulia et al., International Journal of Emerging Trends in Engineering Research, 8(6), June 2020, 2543 - 2550

Website 1 is 0,200 and for Website 2 it is 0,071 . Because the significance for all variables is greater than 0.05 , it can be concluded that the data in the Website 1 and Website 2 variables are normally distributed.

\subsection{Paired Sample T-Test}

To find out if there is a difference between Website 1 and Website 2, the Paired Samples t-Test is performed. The results of the t-Test using the SPSS program are as shown in Figure 16.

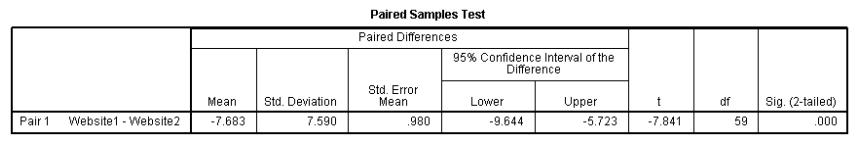

Figure 16: Pair Samples Test

Based on the "Paired Samples Test" output table, it is known that the Sig. (2-tailed) value is $0,000<0.05$. It can be concluded that there is an average difference between Website 1 and Website 2.

Based on the "Paired Samples Test" output table above, it is known that the $t$ value is negative which is $-7,841$. $T$ value is negative because this is because the average value of Website 1 is lower than the average value of Website 2 . In this case, the negative $t$ value can be positive. So that the $t$ value is 7,841 . $T$ table with $\mathrm{df}=59$ and a significance level of $5 \%$ is 2,000 . Because of the value of $t$ arithmetic $>t$ table $(7,841>2,000)$, it can be concluded that there is an average difference between Website 1 and the average value of Website 2.

\section{CONCLUSION AND FUTURE WORK}

From the results of the research conducted, it can be concluded that the proposed User-Centered Design method is better than the previous User-Centered Design method. This can be seen from the SUS calculation results between the two prototypes, which the SUS value for the User-Centered Design method is 65.08 with grade D or rated as "Poor", while the SUS value for the proposed User-Centered Design method is 75.54 with grade B or rated as "Good". The t-test results also indicate that there is a significant effect on the use of the proposed User-Centered Design method compared to the previous User-Centered Design method. From the two points above, we get the result that $\mathrm{H} 0$ is rejected and $\mathrm{H} 1$ is accepted.

We suggest implementing the prototype design method of the User-Centered Design proposal to the actual e-learning system in order to improve development in the future. The results of the proposed User-Centered Design method are expected to help in designing a better system that can bring improvements to the quality of the system itself.

\section{REFERENCES}

1. P. Huang and M. Chiu. Integrating user centered design, universal design and goal, operation, method and selection rules to improve the usability of DAISY player for persons with visual impairments, Applied Ergonomics, vol. 52, pp. 29-42, 2016. https://doi.org/10.1016/j.apergo.2015.06.008

2. J. Y. Mao, K. Vredenburg, P. W. Smith, and T. Carey. The state of user-centered design practice, Communications of the ACM, vol. 48, no. 3, pp. 105-109, 2005. https://doi.org/10.1145/1047671.1047677

3. T. Issa and P. Isaias. Sustainable Design - HCI, Usability and Environmental Concerns, Springer-Verlag London, 2015.

4. International Standard Organization, ISO 9241-11, 1998.

5. A. M. Erman and H. Fawareh. Impact cultural-quality factors on successes and failures software system, Int. J. Emerg. Trends Eng. Res., vol. 8, no. 5, pp. 1656-1662, 2020. https://doi.org/10.30534/ijeter/2020/26852020

6. International Standard Organization, ISO 9241-210, 2010.

7. M. Brhel, H. Meth, A. Maedche, and K. Werder. Exploring principles of user-centered agile software development: A literature review, Information and. Software. Technology, vol. 61, pp. 163-181, 2015.

8. S. Hadjerrouit. Developing Web-Based Learning Resources in School Education: A User-Centered Approach, Interdisciplinary Journal of E-Learning and Learning Objects, vol. 6, 2010.

9. D. A. Becker and L. Yannotta. Modeling a Library Website Redesign Process: Developing a User-Centered Website Through Usability Testing, Information Technology and Libraries, pp. 6-22, March 2013.

10. B. Göransson, J. Gulliksen, and I. Boivie. The usability design process - Integrating user-centered systems design in the software development process, Software Process Improvement and Practice, vol. 8, no. 2, pp. 111-131, 2003.

11. K. Pohl and C. Rupp. Requirements Engineering Fundamentals, 2nd Edition, USA: Rocky Nook Inc., 2015.

12. S. Arikunto. Prosedur Penelitian Suatu Pendekatan Praktik, Jakarta: PT. Rineka Cipta, 2013.

13. T. Taniredja and H. Mustafidah. Penelitian Kuantitatif Sebuah Pengantar, Bandung: Alfabeta, 2012.

14. H. M. Kalyani. Apa itu Persona? Penerapan persona pada proyek, pp. 4-7, 2020.

15. J. Brooke. SUS - A quick and dirty usability scale, Usability Evaluation in Industry, vol. 189, no. 194, pp. 4-7, 1986.

16. A. W. Soejono, A. Setyanto, A. F. Sofyan, and W. Anova. Evaluasi Usability Website UNRIYO Menggunakan System Usability Scale (Studi Kasus: Website UNRIYO), Jurnal Teknologi. Informasi, vol. XIII, no. 1, pp. 29-37, 2018.

17. M. B. Dr. Riduwan and M. S. Dr. Sunarto. Pengantar Statistika untuk Penelitian Pendidikan, Sosial, Ekonomi Komunikasi, dan Bisnis. 2011.

18. M. A. I. Iberahim, et al. Development of virtual reality (VR) application for fine motor stroke rehabilitation, Int. J. Emerg. Trends Eng. Res., vol. 8, no. 5, pp. 1952-1958, 2020

https://doi.org/10.30534/ijeter/2020/79852020 